\title{
Targeting androgen receptor signaling: a historical perspective
}

\author{
Alastair H Davies ${ }^{1}$ and Amina Zoubeidi1,2 \\ 1Department of Urologic Sciences, University of British Columbia, Vancouver, British Columbia, Canada \\ 2Vancouver Prostate Centre, Vancouver, British Columbia, Canada
}

Correspondence should be addressed to A Zoubeidi: azoubeidi@prostatecentre.com

This paper is part of a thematic review section celebrating 80 Years of Androgen Deprivation as a Treatment for Prostate Cancer. The guest editors for this section were Amina Zoubeidi and Paramita Ghosh. Amina Zoubeidi was not involved in the review or editorial process for this paper, on which she is listed as an author.

\begin{abstract}
The first case of prostate cancer was identified by histological examination by Adams, a surgeon at The London Hospital, in 1853. In his report, Adams noted that the condition was 'a very rare disease'. Now, over 150 years later, with increased life expectancy and screening, prostate cancer has become one of the most common cancers in men. In the United States alone, nearly 200,000 men are diagnosed with prostate cancer annually and about 33,000 succumb to their disease. Fifty years ago, men were typically diagnosed with prostate cancer in their seventies with disease that had metastasized to the bone and/ or soft tissue. Diagnosis at such an advanced stage was a death sentence, with patients dying within 2 years. The pioneering work of Charles Huggins in the 1940s found that metastatic prostate cancer responds to androgen deprivation therapy (ADT), ushering in the rational use of hormone therapies that have irrevocably changed the course of prostate cancer disease management. Medical castration was the first effective systemic targeted therapy for any cancer and, to this day, androgen ablation remains the mainstay of prostate cancer therapy.
\end{abstract}

\section{Key Words}

- androgen receptor

- anti-hormone

- endocrine therapy resistance

- hormone receptor

- prostate

\section{Introduction}

Prostate cancer was first identified by Adams in 1853. Adams noted that the condition was 'a very rare disease' (Adams 1853). Prostate cancer has become one of the most common cancers in men: nearly 200,000 men are diagnosed with prostate cancer annually in the USA alone, and about 33,000 succumb to the disease (Siegel et al. 2020). Medical castration was the first effective systemic targeted therapy for any cancer and, to this day, androgen ablation remains the mainstay of prostate cancer therapy (Fig. 1).

\section{The discovery of androgen deprivation therapy}

The concept of ADT to control prostate cancer can be traced back to 1789 when a Scottish surgeon, John Hunter, described seasonal variations in the size of the testicles and prostate gland in animals (Hunter 1837). He went on to demonstrate that castration in young male animals prevented further growth of the prostate, while in adults, it caused atrophy. Further evidence for Hunter's theory of a direct connection between the testes and prostate gland came from his observation that aging eunuchs c) 2021 Society for Endocrinology Published by Bioscientifica Ltd. Printed in Great Britain 


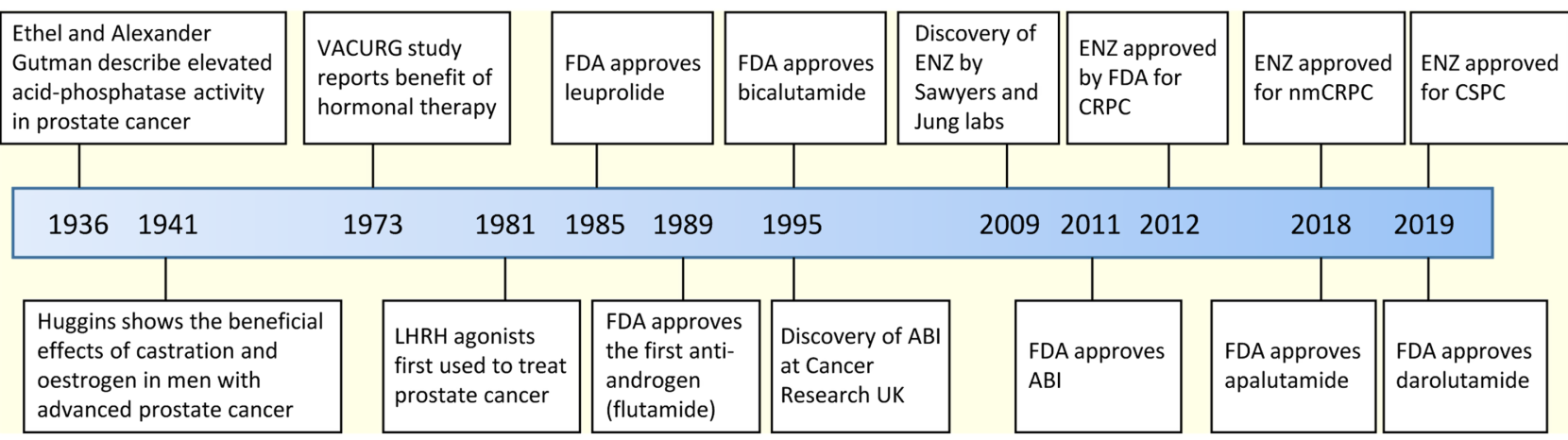

Figure 1

History/timeline of hormone therapy.

never suffered from symptoms of a hypertrophied prostate (Home 1811). On the basis of these early observations, the second half of the nineteenth century was marked by a growing interest in orchiectomy for the treatment of prostatic hyperplasia. Most notably, in 1895, the surgeon William White was the first to report symptomatic improvement in patients with an enlarged prostate treated with castration (White 1895). Numerous reports on the efficacy of castration therapy followed (Cabot 1896, White 1904); however, due to surgical morbidity prevalent at the time, the method fell into disrepute.

In the late 1930s and early 1940s, the exquisite sensitivity of prostate cancer to hormones began to be realized. Seminal work by Ethel Gutman and Alexander Gutman, which discovered serum acid-phosphatase levels are increased in patients with metastatic prostate cancer (Gutman et al. 1936, Gutman \& Gutman 1938), laid the foundation for studying hormonal manipulations on prostatic function and measuring serum acid-phosphatase as a readout for castration. Notably, it was the pioneering experimental studies of Charles Huggins that linked androgens to malignant prostatic growth (Huggins \& Hodges 1941). Huggins was born in Nova Scotia, Canada. After graduating from Harvard Medical School, he spent his internship and residency at the University of Michigan under the stewardship of the prominent surgeon Frederick A. Coller, before joining the University of Chicago in 1927.

In theoriginalstudyby Hugginsand hisstudent, Clarence Hodges, eight patients with metastatic prostate cancer were treated by either castration or estrogen (stilbesterol) therapy to reduce serum testosterone levels. Remarkably, serum acid-phosphatase levels decreased in patients following oral estrogen administration, which was concordant with an appreciable improvement in patient weight, appetite, hematocrit, and, importantly, pain management (Huggins $\&$ Hodges 1941). From these findings, Huggins concluded that prostate cancer is influenced by androgenic activity in the body and could be inhibited by eliminating androgens, either through surgical castration or neutralization of their activity by estrogen injection. The fundamental importance of these findings was acknowledged in 1966 when Charles Huggins as awarded the Nobel Prize in Physiology and Medicine, with the Nobel Committee proclaiming Huggins' work had 'already given many years of an active and useful life to patients with advanced prostate cancer over the entire civilized world - patients who would have been lost to other forms of therapy'.

Huggins' work led to larger clinical studies assessing castration in men with advanced prostate cancer. One of the most important was a series of randomized studies in the 1960s organized by the Veterans Administration Cooperative Urologic Research Group (VACURG), which assessed treating prostate cancer patients with the oral estrogen diethylstilbesterol (DES) (Byar 1972). The initial study of $\sim 3500$ patients concluded that DES treatment was as effective as orchiectomy in treating prostate cancer; however, a number of problems with systemic hormone therapy were exposed. First, lowering serum testosterone levels with estrogen yielded substantial cardiovascular and thromboembolic toxicity (Blackard 1975). Second, it became increasingly evident that androgen ablation, via surgical castration or estrogen administration, was merely palliative and not sufficient to cure patients of prostate cancer. Even Huggins, in the conclusion of his initial paper describing androgen ablation noted, 'in many cases, regression of the neoplasm is not complete' (Huggins et al. 1941). Knowing that, in addition to the testes, the adrenal glands produce low levels of androgens, it was postulated that adrenal androgen production may support prostate cancer recurrence. This was supported by the observation of hyper-function of the adrenal cortex, as measured by increased 17-ketosteroid secretion, in patients following orchiectomy (Satterthwaite 
et al. 1941). Huggins and Scott performed the first bilateral adrenalectomy in 1945, which they showed to have a transient palliative effect in patients who failed medical or surgical castration (Huggins \& Scott 1945). However, this procedure never gained acceptance due to the unpredictable results and severe side effects of hypocortisolism.

\section{New approaches to regulating androgen production manipulating LHRH}

The significant biochemical and psychosocial side effects associated with surgical orchiectomy or estrogen therapy fueled the search for new strategies to block androgen production or its interaction within prostate tissue. Two years before the publication of the first VACURG study, Andrew Schally and Roger Guillemin independently discovered the structure of the hypothalamic hormone known as luteinizing hormone (LH)-releasing hormone (LHRH; also known as gonadotrophin-releasing hormone (Schally et al. 1971, Guillemin \& Burgus 1972)). Pulsatile release of LHRH from the hypothalamus induces the anterior pituitary to produce LH, which, in turn, travels to the Leydig cells of the testes to activate testosterone production. Schally and Guillemin investigated ways to manipulate the hypothalamic-pituitary-gonadal axis, developing the first synthetic peptide agonists of LHRH (Tolis et al. 1982).

Several synthetic LHRH agonists were developed for clinical use during the 1980s, including leuprolide (Lupron), goserelin (Zoladex), buserelin (Suprefact), and nafarelin (Synarel). Early studies by Schally and others showed that chronic use of LHRH agonists lowers testosterone levels by stable suppression of pituitary LH, and consequently androgen secretion from the testes (Auclair et al. 1977, Sandow et al. 1978, Vilchez-Martinez et al. 1979). In particular, patients with advanced prostate cancer treated daily with LHRH agonists experienced a $75 \%$ suppression in serum testosterone levels, a decrease or normalization of plasma acid-phosphatase levels, and a marked reduction in cancer-associated bone pain (Tolis et al. 1982). However, LHRH agonists produce a rapid, but transient increase in serum $\mathrm{LH}$ and hence, testosterone levels - termed a 'testosterone flare' - which was associated with pain and obstructive symptoms. Despite this, LHRH agonists have become the de facto method for ADT as they exhibit less cardiovascular toxicity compared to estrogen therapy (Lepor \& Shore 2012). For his work, Schally received the Nobel Prize in Physiology and Medicine in 1977.

Direct inhibition of the LHRH receptor using pure antagonists has also been explored. Although these agents were initially developed for contraceptive purposes, degarelix gained United States Food and Drug Administration (FDA) approval for the treatment of hormone-sensitive prostate cancer in 2008 (Klotz et al. 2008). Importantly, unlike LHRH agonist therapy, the testosterone flare is not observed with LHRH antagonists. Moreover, time to castration was reduced to 3 days compared to about a month with leuprolide (Clinton et al. 2017), making LHRH antagonists particularly wellsuited for metastatic hormone-naïve tumors. However, these agents have not been without controversy; a recent study unexpectedly found that neoadjuvant degarelix is associated with elevated levels of intratumoral didydrotestosterone (DHT; Sayyid et al. 2017). Further development of LHRH antagonists has largely stalled and, presently, degarelix remains the only approved LHRH antagonist for the treatment of prostate cancer.

To combat the adverse effects and poor quality of life associated with ADT, namely sexual and endocrine dysfunction as well as changes in body composition, interest turned to cyclical administration of ADT, which enables cycling recovery of serum testosterone levels. In 1986, the first study of intermittent ADT reported improved quality of life in patients with symptomatic prostate cancer following cessation of DES therapy and, following re-emergence of symptomatic disease (mean time of 8 months), all patients demonstrated a clinical response upon re-initiation of ADT (Klotz et al. 1986). Following this, multiple phase II trials and meta-analyses confirmed the safety and feasibility of intermittent ADT as a treatment approach (Goldenberg et al. 1995, Shaw et al. 2007). However, while sexual outcomes and cost-savings favor intermittent therapy, recent clinical trials have shown no benefit in oncological outcomes between intermittent and continuous ADT (Perera et al. 2020).

\section{The emergence of androgen receptor- targeted therapies}

In the late 1960s the androgen receptor (AR) was independently discovered and characterized by three investigators: Shutsung Liao (Anderson \& Liao 1968), Nicholas Bruchovsky (Bruchovsky \& Wilson 1968), and Ian Mainwaring (Mainwaring 1969). The first anti-androgen, cyproterone, was discovered serendipitously through a chemical screen. An acetate group was subsequently added to generate cyproterone acetate (CPA), which exhibited increased anti-androgenic potency (Neumann 1994). The earliest studies of CPA found the administration to https://erc bioscientifica.com https://doi.org/10.1530/ERC-21-0116 (c) 2021 Society for Endocrinology Published by Bioscientifica Ltd. Printed in Great Britain 
decrease the size and function of the prostate in dogs and rats (Neri et al. 1968, Geller et al. 1969). Some response was also reported in human prostate adenocarcinomas (Geller et al. 1968). CPA directly competes with testosterone and DHT binding to the AR, while simultaneously inhibiting progesterone receptors in the pituitary to inhibit the release of LH and, in turn, decrease serum testosterone (Varenhorst et al. 1982). In a phase III trial, CPA was shown to be as effective as medical castration with DES (Pavone-Macaluso et al. 1986), leading to its approval as the first anti-androgen for the treatment of prostate cancer in the late 1980s.

The limitations of CPA, mainly its association with severe sexual dysfunction to a level mimicking surgical castration, fueled the search for non-steroidal antiandrogens (NSAAs) that do not have these side effects. This led to the discovery of flutamide in the 1970s (Liao et al. 1974), which became the first NSAA to be approved by the FDA in 1989 for use in treating prostate cancer. Additional NSAAs have subsequently been developed and approved for clinical use, including bicalutamide in 1995 (Newling 1990) and nilutamide in 1996 (Janknegt 1993). Although direct comparisons between the abovementioned anti-androgen therapies is not available, bicalutamide has advantages in terms of its safety profile. In particular, hepatotoxicity, a serious side effect of flutamide and nilutamide, is relatively uncommon with bicalutamide (Wirth et al. 2007). Today, bicalutamide remains the most widely used anti-androgen for advanced prostate cancer.

As these new agents were being developed throughout the 1980-1990s, it became clear that monotherapies targeting the AR signaling axis would be ineffective in curing patients with prostate cancer. The next logical step, accordingly, was to combine therapies to both reduce the amount of testosterone released from the testes (e.g. LHRH agonists) as well as block androgen action in prostate cells using NSAAs. This idea was initially proposed by Fernand Labrie, a Canadian endocrinologist, in 1982 (Labrie et al. 1982, Lefebvre et al. 1982). One of the earliest clinical studies of combined androgen blockade, published by David Crawford and colleagues in 1989, reported that combining leuprolide and flutamide produced a slightly longer median length of survival compared to leuprolide treatment alone (Crawford et al. 1989). The results of this clinical trial yield a significant shift in treatment philosophy. A total of 27 phase III clinical trials using various combinations of androgen deprivation were subsequently performed; however, shockingly, only three showed a statistically significant benefit for combined androgen blockade compared to a single agent alone (Laufer et al. 2000). These trials have been subjected to independent meta-analyses (Caubet et al. 1997, Bennett et al. 1999); it was concluded that combined androgen blockade does not yield a significant survival benefit.

\section{Doubling down on AR targeted therapy, the new generation inhibitors}

Despite clinically significant responses to early systemic anti-androgen therapies, such as bicalutamide, tumors ultimately relapse to a castration-resistant state termed castration-resistant prostate cancer (CRPC). Our understanding of this phenomenon can be traced back to a pair of studies published in 1991 that reported nearly all primary prostate tumors, including those that recurred after androgen ablation therapy, continue to express the AR (Sadi et al. 1991, van der Kwast et al. 1991). A subsequent investigation found that $30 \%$ of CRPC tumors harbored genomic amplification of the $A R$ locus, which was not detected in matched samples obtained prior to ADT (Visakorpi et al. 1995). A variety of AR molecular alterations, such as mutations and polymorphisms, have since been described (Watson et al. 2015). Notably, point mutations are associated with AR promiscuity and paradoxical responses to anti-androgen therapies; for example, bicalutamide activates the AR with a mutation in codon 741 (Hara et al. 2003). These findings provided the rational for drug discovery screens to identify novel antiandrogens offering a more durable response.

The azole antifungal, ketoconazole, provided the first clinical evidence that more complete androgen suppression can lead to desirable clinical outcomes in the castration-resistant setting. Ketoconazole exerts its antitumor activity through blockade of CYP17, the key family of enzymes responsible for adrenal and intratumoral androgen synthesis (Santen et al. 1983). Unfortunately, lack of potency and specificity for CYP17 yielded significant toxicities (De Coster et al. 1986). This led researchers at Cancer Research UK to design and evaluate more effective inhibitors of the CYP17 enzyme, which ultimately resulted in the development of abiraterone (Barrie et al. 1994, Potter et al. 1995, Rowlands et al. 1995). In 1996, abiraterone was out-licensed to Boehringer Ingelheim; however, developmental progress was hampered by concerns about possible side effects of blocking CYP17 as well as a lack of interest in hormonal therapies for late-stage 'hormone refractory' prostate cancer. The later realization that advanced prostate cancer remains dependent on testosterone paved the way for the licensing of abiraterone to Cougar Biotechnology (later acquired by Johnson \& (c) 2021 Society for Endocrinology Published by Bioscientifica Ltd. Printed in Great Britain 
Johnson) in 2004. The first phase I study, spearheaded by Dr Johan de Bono and Dr Gert Attard, enrolled 21 men with chemotherapy-naive CRPC and found that abiraterone-treated patients experienced significant tumor shrinkage and dramatic falls in prostate-specific antigen (PSA) levels (Attard et al. 2008). Less than a year later, these findings were confirmed in a larger phase I/II study (Danila et al. 2010). In 2010, the pivotal phase III COU-AA-301 trial (NCT00638690) showed increased survival in patients given abiraterone (de Bono et al. 2011), paving the way for FDA approval in 2011.

In parallel with the development of abiraterone in the UK, researchers in the United States - led by Dr Charles Sawyers and Dr Michael Jung - utilized a rational drug screening and iteration strategy to identify compounds with activity in prostate cancer models overexpressing the AR (Tran et al. 2009). This led to the clinical development of enzalutamide (formally MDV3100). In contrast to abiraterone, enzalutamide functions to blunt AR signaling by directly binding to the ligand-binding domain of the AR, effectively inhibiting the binding of androgens as well as AR nuclear translocation and association with DNA (Tran et al. 2009). Given the relative efficacy and safety profile of enzalutamide in a phase I/II trial (NCT00510718 (Scher et al. 2010)), two multi-national phase III trials were initiated to evaluate enzalutamide in men with CRPC. The phase III AFFIRM trial (NCT00974311), which assessed enzalutamide in men with metastatic CRPC previously treated with docetaxel-based chemotherapy, demonstrated an overwhelmingly positive survival benefit (Scher et al. 2012). A similar survival benefit was found in the second phase III trial, PREVAIL (NCT01212991), which was conducted in men with asymptomatic metastatic CRPC without prior chemotherapy (Beer et al. 2014). Most recently, in the phase III ARCHES trial (NCT02677896), enzalutamide was found to significantly reduce the risk of metastatic progression or death in the castration-sensitive (CSPC) setting (Armstrong et al. 2019). On the basis of these trials, enzalutamide was approved by the FDA in 2012 for late-stage CRPC, which was later expanded to the setting of non-metastatic CRPC (nmCRPC) in 2018 and metastatic CSPC in 2019.

Apalutamide and darolutamide, AR antagonists designed to supersede enzalutamide, were first approved by the FDA in 2018 and 2019, respectively, for the treatment of nmCRPC. In contrast with enzalutamide, darolutamide remains active against mutated AR. It also has an improved safety profile as it does not cross the blood-brain barrier (Moilanen et al. 2015). However, independent clinical trials assessing enzalutamide (PROSPER (Hussain et al. 2018)), apalutamide (SPARTAN (Smith et al. 2018)), and darolutamide (ARAMIS (Fizazi et al. 2019)) in the nmCRPC setting all reported to prolong metastasis-free survival by $\sim 2$ years. As all three drugs have a similar benefit, clinical decision-making is largely based on cost and patient co-morbidities.

\section{Looking toward the next decade of AR targeted therapies}

Despite the successes of AR pathway inhibition for the treatment of prostate cancer, the efficacy is short-lived in many patients due to emergent resistance mechanisms. Cross-resistance between currently available AR pathway inhibitors has limited treatment options following tumor recurrence. For example, adding abiraterone at the time of enzalutamide resistance was not effective (PLATO trial (Attard et al. 2018)) and, similarly, combining the agents upfront was also not beneficial (Alliance A031201 trial (Morris et al. 2019)).

To offset the possibility of persistent 'AR-driven' prostate cancer, new therapeutic paradigms are currently under investigation. Of particular promise is the development of selective AR degraders. Notably, in preclinical studies, these agents have shown efficacy against enzalutamide-resistant AR as well as AR splice variants (Ponnusamy et al. 2019, Kregel et al. 2020). Another innovative therapeutic strategy being explored involves alternating and/or rapid cycling of ADT and androgen therapy (termed bipolar androgen therapy, BAT) to induce supraphysiological levels of testosterone to potentially prolong or restore responses to enzalutamide. In a phase II trial, 15 of 21 patients with enzalutamide-resistant CRPC responded to a subsequent re-challenge with enzalutamide following BAT (Teply et al. 2018). Finally, neoadjuvant ADT has shown promise in patients with high-risk localized prostate cancer (Pignot et al. 2018) and, accordingly, multimodal approaches combining local and systemic therapy could offer further therapeutic possibilities. This idea was tested in ongoing STAMPEDE clinical trials with the addition of radiotherapy to primary tumor to hormone therapy plus docetaxel in patients with newly diagnosed low burden metastatic disease. The study revealed that $32 \%$ reduction in risk of death and $41 \%$ reduction in failure-free survival while high burden disease did not reach statistical significance (Parker et al. 2018). This is only one example of the power of the STAMPEDE trials that has being ongoing and adding patients and different arms since 2005. This has yielded practice-changing finding and contributing to three new standard of care first-line treatment options for patient with metastatic hormone-sensitive prostate cancer 
(mHSPC), including the combination of chemotherapy with hormone therapy (Sweeney et al. 2015).

When reflecting on the future of targeting the AR signaling pathway, it is important to appreciate the heterogeneity that exists within prostate tumors. The emergence of 'AR-indifferent' prostate cancer variants such as neuroendocrine prostate cancer (NEPC), particularly following potent AR targeted therapy (Davies et al. 2018), suggests that targeting the AR alone will be insufficient to cure prostate cancer. Clinical trials combining AR pathway inhibitors with AR agnostic therapeutic strategies, such as immunotherapy (e.g. PD1/PDL1 blockade) or epigenetic therapies (e.g. EZH2 inhibition) as well as targeting the DNA repair using PARP inhibitor are ongoing. These types of combination approaches might be the next generation of prostate cancer therapies.

\section{Declaration of interest}

The authors declare that there is no conflict of interest that could be perceived as prejudicing the impartiality of this review.

\section{Funding}

This research was supported by funding from the Terry Fox Research Institute New Frontiers Program (F15-05505; to A Z), the Prostate Cancer Foundation (to $A \mathrm{Z}$ and $\mathrm{H} B$ ), the Canadian Institutes of Health Research (to A D and A Z), Prostate Cancer Canada (T2013-01; to A Z) and Prostate Cancer Foundation Young Investigator Award (to A D).

\section{References}

Adams J 1853 The case of scirrhous of the prostate gland with corresponding affliction of the lymphatic glands in the lumbar region and in the pelvis. Lancet $\mathbf{1} 393$.

Anderson KM \& Liao S 1968 Selective retention of dihydrotestosterone by prostatic nuclei. Nature 219 277-279. (https://doi.org/10.1038/219277a0)

Armstrong AJ, Szmulewitz RZ, Petrylak DP, Holzbeierlein J, Villers A, Azad A, Alcaraz A, Alekseev B, Iguchi T, Shore ND, et al. 2019 ARCHES: a randomized, phase III study of androgen deprivation therapy with enzalutamide or placebo in men with metastatic hormone-sensitive prostate cancer. Journal of Clinical Oncology 37 2974-2986. (https://doi. org/10.1200/JCO.19.00799)

Attard G, Reid AH, Yap TA, Raynaud F, Dowsett M, Settatree S, Barrett M, Parker C, Martins V, Folkerd E, et al. 2008 Phase I clinical trial of a selective inhibitor of CYP17, abiraterone acetate, confirms that castration-resistant prostate cancer commonly remains hormone driven. Journal of Clinical Oncology 26 4563-4571. (https://doi. org/10.1200/JCO.2007.15.9749)

Attard G, Borre M, Gurney H, Loriot Y, Andresen-Daniil C, Kalleda R, Pham T, Taplin ME \& PLATO Collaborators 2018 Abiraterone alone or in combination with enzalutamide in metastatic castration-resistant prostate cancer with rising prostate-specific antigen during enzalutamide treatment. Journal of Clinical Oncology 36 2639-2646. (https://doi.org/10.1200/JCO.2018.77.9827)

Auclair C, Kelly PA, Labrie F, Coy DH \& Schally AV 1977 Inhibition of testicular luteinizing hormone receptor level by treatment with a potent luteinizing hormone-releasing hormone agonist of human chorionic gonadotropin. Biochemical and Biophysical Research Communications 76 855-862. (https://doi.org/10.1016/0006291x(77)91579-0)

Barrie SE, Potter GA, Goddard PM, Haynes BP, Dowsett M \& Jarman M 1994 Pharmacology of novel steroidal inhibitors of cytochrome P450(17) alpha (17 alpha-hydroxylase/C17-20 lyase). Journal of Steroid Biochemistry and Molecular Biology 50 267-273. (https://doi. org/10.1016/0960-0760(94)90131-7)

Beer TM, Armstrong AJ, Rathkopf DE, Loriot Y, Sternberg CN, Higano CS, Iversen P, Bhattacharya S, Carles J, Chowdhury S, et al. 2014 Enzalutamide in metastatic prostate cancer before chemotherapy. New England Journal of Medicine 371 424-433. (https://doi.org/10.1056/ NEJMoa1405095)

Bennett CL, Tosteson TD, Schmitt B, Weinberg PD, Ernstoff MS \& Ross SD 1999 Maximum androgen-blockade with medical or surgical castration in advanced prostate cancer: a meta-analysis of nine published randomized controlled trials and 4128 patients using flutamide. Prostate Cancer and Prostatic Diseases 2 4-8. (https://doi. org/10.1038/sj.pcan.4500265)

Blackard CE 1975 The Veterans' Administration Cooperative Urological Research Group studies of carcinoma of the prostate: a review. Cancer Chemotherapy Reports 59 225-227.

Bruchovsky N \& Wilson JD 1968 The intranuclear binding of testosterone and 5-alpha-androstan-17-beta-ol-3-one by rat prostate. Journal of Biological Chemistry 243 5953-5960. (https://doi.org/10.1016/S00219258(18)94513-8)

Byar DP 1972 Treatment of prostatic cancer: studies by the Veterans Administration Cooperative Urological Research Group. Bulletin of the New York Academy of Medicine 48 751-766.

Cabot AT 1896 II. The question of castration for enlarged prostate. Annals of Surgery 24 265-309. (https://doi.org/10.1097/00000658-18960700000036)

Caubet JF, Tosteson TD, Dong EW, Naylon EM, Whiting GW, Ernstoff MS \& Ross SD 1997 Maximum androgen blockade in advanced prostate cancer: a meta-analysis of published randomized controlled trials using nonsteroidal antiandrogens. Urology 49 71-78. (https://doi. org/10.1016/S0090-4295(96)00325-1)

Clinton TN, Woldu SL \& Raj GV 2017 Degarelix versus luteinizing hormone-releasing hormone agonists for the treatment of prostate cancer. Expert Opinion on Pharmacotherapy 18 825-832. (https://doi.org /10.1080/14656566.2017.1328056)

Crawford ED, Eisenberger MA, Mcleod DG, Spaulding JT, Benson R, Dorr FA, Blumenstein BA, Davis MA \& Goodman PJ 1989 A controlled trial of leuprolide with and without flutamide in prostatic carcinoma. New England Journal of Medicine 321 419-424. (https://doi.org/10.1056/ NEJM198908173210702)

Danila DC, Morris MJ, De Bono JS, Ryan CJ, Denmeade SR, Smith MR, Taplin ME, Bubley GJ, Kheoh T, Haqq C, et al. 2010 Phase II multicenter study of abiraterone acetate plus prednisone therapy in patients with docetaxel-treated castration-resistant prostate cancer. Journal of Clinical Oncology 28 1496-1501. (https://doi.org/10.1200/JCO.2009.25.9259)

Davies AH, Beltran H \& Zoubeidi A 2018 Cellular plasticity and the neuroendocrine phenotype in prostate cancer. Nature Reviews: Urology 15 271-286. (https://doi.org/10.1038/nrurol.2018.22)

de Bono JS, Logothetis CJ, Molina A, Fizazi K, North S, Chu L, Chi KN, Jones RJ, Goodman OB, Saad F, et al. 2011 Abiraterone and increased survival in metastatic prostate cancer. New England Journal of Medicine 364 1995-2005. (https://doi.org/10.1056/NEJMoa1014618)

De Coster R, Caers I, Coene MC, Amery W, Beerens D \& Haelterman C 1986 Effects of high dose ketoconazole therapy on the main plasma testicular and adrenal steroids in previously untreated prostatic cancer patients. Clinical Endocrinology 24 657-664. (https://doi. org/10.1111/j.1365-2265.1986.tb01662.x)

Fizazi K, Shore N, Tammela TL, Ulys A, Vjaters E, Polyakov S, Jievaltas M, Luz M, Alekseev B, Kuss I, et al. 2019 Darolutamide in nonmetastatic, https://erc bioscientifica com

https://doi.org/10.1530/ERC-21-0116
(C) 2021 Society for Endocrinology Published by Bioscientifica Ltd. Printed in Great Britain 
castration-resistant prostate cancer. New England Journal of Medicine 380 1235-1246. (https://doi.org/10.1056/NEJMoa1815671)

Geller J, Vazakas G, Fruchtman B, Newman H, Nakao K \& Loh A 1968 The effect of cyproterone acetate on advanced carcinoma of the prostate. Surgery, Gynecology and Obstetrics 127 748-758.

Geller J, Van Damme O, Garabieta G, Loh A, Rettura J \& Seifter E 1969 Effect of cyproterone acetate on $3 \mathrm{H}$-testosterone uptake and enzyme synthesis by the ventral prostate of the rat. Endocrinology $\mathbf{8 4}$ 13330-13335. (https://doi.org/10.1210/endo-84-6-1330)

Goldenberg SL, Bruchovsky N, Gleave ME, Sullivan LD \& Akakura K 1995 Intermittent androgen suppression in the treatment of prostate cancer: a preliminary report. Urology 45 839-844; discussion 844-845. (https://doi.org/10.1016/s0090-4295(99)80092-2)

Guillemin R \& Burgus R 1972 The hormones of the hypothalamus. Scientific American 227 24-33. (https://doi.org/10.1038/ scientificamerican1172-24)

Gutman AB \& Gutman EB 1938 An 'acid' phosphatase occurring in the serum of patients with metastasizing carcinoma of the prostate gland. Journal of Clinical Investigation 17 473-478. (https://doi.org/10.1172/ JCI100974)

Gutman EB, Sproul EE \& Gutman AB 1936 Significance of increased phosphatase activity of bone at the site of osteoplastic metastases secondary to carcinoma of the prostate gland. American Journal of Cancer 28 485-495. (https://doi.org/10.1158/ajc.1936.485a)

Hara T, Miyazaki J, Araki H, Yamaoka M, Kanzaki N, Kusaka M \& Miyamoto M 2003 Novel mutations of androgen receptor: a possible mechanism of bicalutamide withdrawal syndrome. Cancer Research 63 149-153.

Home E 1811 Practical Observations on the Treatment of the Diseases of the Prostate Gland. London: G. and W. Nicol.

Huggins C \& Hodges CV 1941 Studies on prostate cancer: I. The effect of castration, of estrogen and of androgen injection on serum phosphatases in metastatic carcinoma of the prostate. Cancer Research 1 293-297.

Huggins C \& Scott WW 1945 Bilateral adrenalectomy in prostatic cancer: clinical features and urinary excretion of 17-ketosteroids and estrogen. Annals of Surgery 122 1031-1041. (https://doi.org/10.1097/00000658194512260-00012)

Huggins C, Stephens RC \& Hodges CV 1941 Studies on prostatic cancer: 2. The effects of castration on advanced carcinoma of the prostate gland. Archives of Surgery 43 209-223. (https://doi.org/10.1001/ archsurg.1941.01210140043004)

Hunter J 1837 The Works of John Hunter F. R. S. with Notes. London: Longman.

Hussain M, Fizazi K, Saad F, Rathenborg P, Shore N, Ferreira U, Ivashchenko P, Demirhan E, Modelska K, Phung, et al. 2018 Enzalutamide in men with nonmetastatic, castration-resistant prostate cancer. New England Journal of Medicine 378 2465-2474. (https://doi. org/10.1056/NEJMoa1800536)

Janknegt RA 1993 Total androgen blockade with the use of orchiectomy and nilutamide (Anandron) or placebo as treatment of metastatic prostate cancer. Anandron International Study Group. Cancer $\mathbf{7 2}$ (Supplement) 3874-3877. (https://doi.org/10.1002/10970142(19931215)72:12+<3874::aid-cncr2820721722>3.0.co;2-\#)

Klotz L, Boccon-Gibod L, Shore ND, Andreou C, Persson BE, Cantor P, Jensen JK, Olesen TK \& Schroder FH 2008 The efficacy and safety of degarelix: a 12-month, comparative, randomized, open-label, parallelgroup phase III study in patients with prostate cancer. BJU International 102 1531-1538. (https://doi.org/10.1111/j.1464-410X.2008.08183.x)

Klotz LH, Herr HW, Morse MJ \& Whitmore Jr WF 1986 Intermittent endocrine therapy for advanced prostate cancer. Cancer 58 2546-2550. (https://doi.org/10.1002/1097-0142(19861201)58:11<2546::aidcncr2820581131>3.0.co;2-n)

Kregel S, Wang C, Han X, Xiao L, Fernandez-Salas E, Bawa P, Mccollum BL, Wilder-Romans K, Apel IJ, Cao X, et al. 2020 Androgen receptor degraders overcome common resistance mechanisms developed during prostate cancer treatment. Neoplasia 22 111-119. (https://doi. org/10.1016/j.neo.2019.12.003)

Labrie F, Dupont A, Belanger A, Cusan L, Lacourciere Y, Monfette G, Laberge JG, Emond JP, Fazekas AT, Raynaud JP, et al. $1982 \mathrm{New}$ hormonal therapy in prostatic carcinoma: combined treatment with an LHRH agonist and an antiandrogen. Clinical and Investigative Medicine 5 267-275.

Laufer M, Denmeade SR, Sinibaldi VJ, Carducci MA \& Eisenberger MA 2000 Complete androgen blockade for prostate cancer: what went wrong? Journal of Urology $1643-9$. (https://doi.org/10.1016/S00225347(05)67436-8)

Lefebvre FA, Seguin C, Belanger A, Caron S, Sairam MR, Raynaud JP \& Labrie F 1982 Combined long-term treatment with an LHRH agonist and a pure antiandrogen blocks androgenic influence in the rat. Prostate 3 569-578. (https://doi.org/10.1002/pros.2990030606)

Lepor H \& Shore ND 2012 LHRH agonists for the treatment of prostate cancer: 2012. Reviews in Urology 14 1-12.

Liao S, Howell DK \& Chang TM 1974 Action of a nonsteroidal antiandrogen, flutamide, on the receptor binding and nuclear retention of 5 alpha-dihydrotestosterone in rat ventral prostate. Endocrinology 94 1205-1209. (https://doi.org/10.1210/endo-94-4-1205)

Mainwaring WI 1969 A soluble androgen receptor in the cytoplasm of rat prostate. Journal of Endocrinology 45 531-541. (https://doi.org/10.1677/ joe.0.0450531)

Moilanen AM, Riikonen R, Oksala R, Ravanti L, Aho E, Wohlfahrt G, Nykanen PS, Tormakangas OP, Palvimo JJ \& Kallio PJ 2015 Discovery of ODM-201, a new-generation androgen receptor inhibitor targeting resistance mechanisms to androgen signaling-directed prostate cancer therapies. Scientific Reports 5 12007. (https://doi.org/10.1038/srep12007)

Morris MJ, Heller G, Bryce AH, Armstrong AJ, Beltran H, Hahn OM, Mcgary EC, Mehan PT, Goldkorn A, Roth BJ, et al. 2019 Alliance A031201: a phase III trial of enzalutamide (ENZ) versus enzalutamide, abiraterone, and prednisone (ENZ/AAP) for metastatic castration resistant prostate cancer (mCRPC). Journal of Clinical Oncology 37 5008-5008. (https://doi.org/10.1200/JCO.2019.37.15_suppl.5008)

Neri RO, Casmer C, Zeman WV, Fielder F \& Tabachnick II 1968 Effects of an anti-androgen, SH 714 (6-chlor-delta-6-1,2-alpha-methylen-17-a lpha-hydroxyprogesterone acetate, cyproterone acetate) on canine prostatic hyperplasia. Endocrinology 82 311-317. (https://doi. org/10.1210/endo-82-2-311)

Neumann F 1994 The antiandrogen cyproterone acetate: discovery, chemistry, basic pharmacology, clinical use and tool in basic research. Experimental and Clinical Endocrinology 102 1-32. (https://doi. org/10.1055/s-0029-1211261)

Newling DW 1990 The response of advanced prostatic cancer to a new non-steroidal antiandrogen: results of a multicenter open phase II study of Casodex. European/Australian Co-Operative Group. European Urology 18 (Supplement 3) 18-21. (https://doi.org/10.1159/000463973)

Parker CC, James ND, Brawley CD, Clarke NW, Hoyle AP, Ali A, Ritchie AWS, Attard G, Chowdhury S, Cross W, et al. 2018 Radiotherapy to the primary tumour for newly diagnosed, metastatic prostate cancer (STAMPEDE): a randomised controlled phase 3 trial. Lancet 392 23532366. (https://doi.org/10.1016/S0140-6736(18)32486-3)

Pavone-Macaluso M, De Voogt HJ, Viggiano G, Barasolo E, Lardennois B, De Pauw M \& Sylvester R 1986 Comparison of diethylstilbestrol, cyproterone acetate and medroxyprogesterone acetate in the treatment of advanced prostatic cancer: final analysis of a randomized phase III trial of the European Organization for Research on Treatment of Cancer Urological Group. Journal of Urology 136 624-631. (https:// doi.org/10.1016/s0022-5347(17)44996-2)

Perera M, Roberts MJ, Klotz L, Higano CS, Papa N, Sengupta S, Bolton D \& Lawrentschuk N 2020 Intermittent versus continuous androgen deprivation therapy for advanced prostate cancer. Nature Reviews: Urology 17 469-481. (https://doi.org/10.1038/s41585-020-0335-7)

Pignot G, Maillet D, Gross E, Barthelemy P, Beauval JB, ConstansSchlurmann F, Loriot Y, Ploussard G, Sargos P, Timsit MO, et al. 2018 (c) 2021 Society for Endocrinology Published by Bioscientifica Ltd. Printed in Great Britain 
Systemic treatments for high-risk localized prostate cancer. Nature Reviews: Urology 15 498-510. (https://doi.org/10.1038/s41585-018-0017-x)

Ponnusamy S, He Y, Hwang DJ, Thiyagarajan T, Houtman R, Bocharova V, Sumpter BG, Fernandez E, Johnson D, Du Z, et al. 2019 Orally bioavailable androgen receptor degrader, potential next-generation therapeutic for Enzalutamide-resistant prostate cancer. Clinical Cancer Research 25 67646780. (https://doi.org/10.1158/1078-0432.CCR-19-1458)

Potter GA, Barrie SE, Jarman M \& Rowlands MG 1995 Novel steroidal inhibitors of human cytochrome P45017 alpha (17 alpha-hydroxylaseC17,20-lyase): potential agents for the treatment of prostatic cancer. Journal of Medicinal Chemistry 38 2463-2471. (https://doi.org/10.1021/ jm00013a022)

Rowlands MG, Barrie SE, Chan F, Houghton J, Jarman M, Mccague R \& Potter GA 1995 Esters of 3-pyridylacetic acid that combine potent inhibition of 17 alpha-hydroxylase/C17,20-lyase (cytochrome P45017 alpha) with resistance to esterase hydrolysis. Journal of Medicinal Chemistry 38 4191-4197. (https://doi.org/10.1021/jm00021a008)

Sadi MV, Walsh PC \& Barrack ER 1991 Immunohistochemical study of androgen receptors in metastatic prostate cancer. Comparison of receptor content and response to hormonal therapy. Cancer $\mathbf{6 7}$ 3057-3064. (https://doi.org/10.1002/1097-

0142(19910615)67:12<3057::aid-cncr2820671221>3.0.co;2-s)

Sandow J, Von Rechenberg W, Jerzabek G \& Stoll W 1978 Pituitary gonadotropin inhibition by a highly active analog of luteinizing hormone-releasing hormone. Fertility and Sterility 30 205-209. (https://doi.org/10.1016/s0015-0282(16)43461-8)

Santen RJ, Van Den Bossche H, Symoens J, Brugmans J \& Decoster R 1983 Site of action of low dose ketoconazole on androgen biosynthesis in men. Journal of Clinical Endocrinology and Metabolism 57 732-736. (https://doi.org/10.1210/jcem-57-4-732)

Satterthwaite RW, Hill JH \& Packard EF 1941 Experimental and clinical evidence on the role of the 17 keto-steroids in prostatic carcinoma. Journal of Urology 46 1149-1153. (https://doi.org/10.1016/S00225347(17)71020-8)

Sayyid RK, Evans A, Hersey K, Maloni R, Hurtado-Coll A, Kulkarni G, Finelli A, Zlotta AR, Hamilton R, Gleave M, et al. 2017 A phase II, randomized, open-label study of neoadjuvant degarelix versus LHRH agonist in prostate cancer patients prior to radical prostatectomy. Clinical Cancer Research 23 1974-1980. (https://doi.org/10.1158/10780432.CCR-16-1790)

Schally AV, Arimura A, Kastin AJ, Matsuo H, Baba Y, Redding TW, Nair RM, Debeljuk L \& White WF 1971 Gonadotropin-releasing hormone: one polypeptide regulates secretion of luteinizing and follicle-stimulating hormones. Science 173 1036-1038. (https://doi.org/10.1126/ science.173.4001.1036)

Scher HI, Beer TM, Higano CS, Anand A, Taplin ME, Efstathiou E, Rathkopf D, Shelkey J, Yu EY, Alumkal J, et al. 2010 Antitumour activity of MDV3100 in castration-resistant prostate cancer: a phase 1-2 study. Lancet 375 1437-1446. (https://doi.org/10.1016/S01406736(10)60172-9)

Scher HI, Fizazi K, Saad F, Taplin ME, Sternberg CN, Miller K, De Wit R, Mulders P, Chi KN, Shore ND, et al. 2012 Increased survival with enzalutamide in prostate cancer after chemotherapy. New England Journal of Medicine 367 1187-1197. (https://doi.org/10.1056/NEJMoa1207506)

Shaw GL, Wilson P, Cuzick J, Prowse DM, Goldenberg SL, Spry NA \& Oliver T 2007 International study into the use of intermittent hormone therapy in the treatment of carcinoma of the prostate: a meta-analysis of 1446 patients. BJU International 99 1056-1065. (https://doi.org/10.1111/j.1464-410X.2007.06770.x)
Siegel RL, Miller KD \& Jemal A 2020 Cancer statistics, 2020. CA: A Cancer Journal for Clinicians 70 7-30. (https://doi.org/10.3322/caac.21590)

Smith MR, Saad F, Chowdhury S, Oudard S, Hadaschik BA, Graff JN, Olmos D, Mainwaring PN, Lee JY, Uemura H, et al. 2018 Apalutamide treatment and metastasis-free survival in prostate cancer. New England Journal of Medicine 378 1408-1418. (https://doi.org/10.1056/ NEJMoa1715546)

Sweeney CJ, Chen YH, Carducci M, Liu G, Jarrard DF, Eisenberger M, Wong YN, Hahn N, Kohli M, Cooney MM, et al. 2015 Chemohormonal therapy in metastatic hormone-sensitive prostate cancer. New England Journal of Medicine 373 737-746. (https://doi. org/10.1056/NEJMoa1503747)

Teply BA, Wang H, Luber B, Sullivan R, Rifkind I, Bruns A, Spitz A, Decarli M, Sinibaldi V, Pratz CF, et al. 2018 Bipolar androgen therapy in men with metastatic castration-resistant prostate cancer after progression on enzalutamide: an open-label, phase 2, multicohort study. Lancet: Oncology 19 76-86. (https://doi.org/10.1016/S14702045(17)30906-3)

Tolis G, Ackman D, Stellos A, Mehta A, Labrie F, Fazekas AT, ComaruSchally AM \& Schally AV 1982 Tumor growth inhibition in patients with prostatic carcinoma treated with luteinizing hormone-releasing hormone agonists. PNAS 79 1658-1662. (https://doi.org/10.1073/ pnas.79.5.1658)

Tran C, Ouk S, Clegg NJ, Chen Y, Watson PA, Arora V, Wongvipat J, Smith-Jones PM, Yoo D, Kwon A, et al. 2009 Development of a second-generation antiandrogen for treatment of advanced prostate cancer. Science 324 787-790. (https://doi.org/10.1126/ science.1168175)

van der Kwast TH, Schalken J, Ruizeveld De Winter JA, Van Vroonhoven CC, Mulder E, Boersma W \& Trapman J 1991 Androgen receptors in endocrine-therapy-resistant human prostate cancer. International Journal of Cancer 48 189-193. (https://doi.org/10.1002/ijc.2910480206)

Varenhorst E, Wallentin L \& Carlstrom K 1982 The effects of orchidectomy, estrogens, and cyproterone acetate on plasma testosterone, $\mathrm{LH}$, and FSH concentrations in patients with carcinoma of the prostate. Scandinavian Journal of Urology and Nephrology 16 31-36. (https://doi.org/10.3109/00365598209179637)

Vilchez-Martinez JA, Pedroza E, Arimura A \& Schally AV 1979 Paradoxical effects of D-Trp6-luteinizing hormone-releasing hormone on the hypothalamic-pituitary-gonadal axis in immature female rats. Fertility and Sterility 31 677-682. (https://doi.org/10.1016/s00150282(16)44061-6)

Visakorpi T, Hyytinen E, Koivisto P, Tanner M, Keinanen R, Palmberg C, Palotie A, tammela T, Isola J \& Kallioniemi OP 1995 In vivo amplification of the androgen receptor gene and progression of human prostate cancer. Nature Genetics 9 401-406. (https://doi. org/10.1038/ng0495-401)

Watson PA, Arora VK \& Sawyers CL 2015 Emerging mechanisms of resistance to androgen receptor inhibitors in prostate cancer. Nature Reviews: Cancer 15 701-711. (https://doi.org/10.1038/nrc4016)

White JW 1895 I. The results of double castration in hypertrophy of the prostate. Annals of Surgery 22 1-80. (https://doi.org/10.1097/00000658189507000-00001)

White JW 1904 II. The present position of the surgery of the hypertrophied prostate. Annals of Surgery 40 782-795. (https://doi. org/10.1097/00000658-190412000-00002)

Wirth MP, Hakenberg OW \& Froehner M 2007 Antiandrogens in the treatment of prostate cancer. European Urology 51 306-313; discussion 314. (https://doi.org/10.1016/j.eururo.2006.08.043)

Received in final form 10 June 2021

Accepted 15 June 2021

Accepted Manuscript published online 15 June 2021 https://erc.bioscientifica.com https://doi.org/10.1530/ERC-21-0116 (c) 2021 Society for Endocrinology Published by Bioscientifica Ltd. Printed in Great Britain 